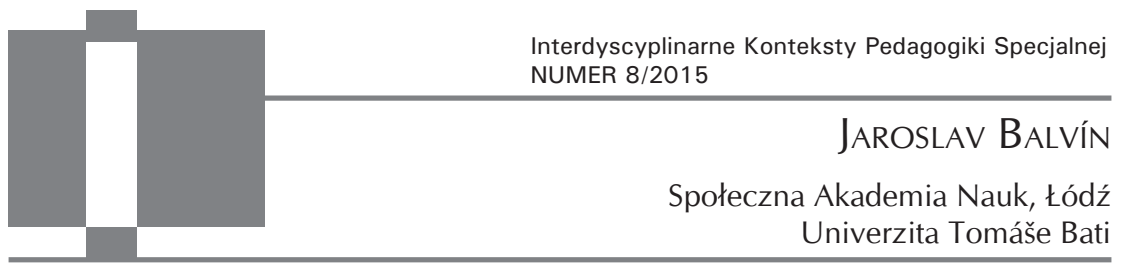

\title{
Role učitele při ovlivňování a zmírňování interetnického napětí ve společnosti
}

\begin{abstract}
Aвsтract: Balvín Jaroslav, The role of teachers in conflict solving and strain weakening between ethnic minories in the society [Rola nauczyciela w rozwiązywaniu i osłabianiu napięć/konfliktów między mniejszościami narodowymi w społeczeństwie]. Interdyscyplinarne Konteksty Pedagogiki Specjalnej, nr 8, Poznań 2015. Pp. 77-91. Adam Mickiewicz University Press. ISBN 978-83-232-2902-5. ISSN 2300-391X.

The article deals with pedeutology and intercultural problems, and that is teachers' attitudes towards Roma children and their parents. It is the reaction on discrimination acts on Roma in Czech Republic in the years 2012-2013.
\end{abstract}

KEY WORDS: teacher, ethnic minories, education, discrimination, Roma.

\section{Vstup}

Učitel má významné místo v situaci výchovy a vzdělávání žáků. Jeho role je nezastupitelná. Z toho vyplývá i jeho odpovědnost v multikulturních situacích, ve vztahu k žákům jiným, odlišným. A těmi jsou $\mathrm{v}$ našem zkoumaném případě žáci romští na různých školách základních a speciálních. Protože největší protiromské akce byly v českých městech na severu Čech Šluknov a Rumburk, provedli jsme právě v těchto městech výzkum a shromáždili jsme i názory 
učitelů, romských i neromských, a dalších odborníků, studentů, na daný problém ve společnosti a možnosti jeho řešení.

\section{Výzkumné téma a jeho společenský význam}

Tématem výzkumu, který je základem našeho textu, nebylo zkoumání role učitele ve vztahu $\mathrm{k}$ romským žákům $\mathrm{v}$ celé šśríi. Náš výzkum jsme zaměřili na jeden společensky závažný fenomén: napětí mezi Romy a neromy ve společnosti. Naší snahou bylo na základě analýzy výpovědí romských a neromských učitelů a odborníků odpovědět na otázku, zdali a jak může učitel komunikacís žáky a rodiči ovlivnit odstraňování a uvolňování tohoto vzájemného napětí. Záměrně jsme si zvolili místo, kde se toto napětí vyhrotilo $v$ protestních akcích ve vztahu k Romům ve Šluknovském výběžku v roce 2011.

\section{Charakteristika a stanovení cílů výzkumu}

Obsahovou analýzou poznatků o událostech ve Šluknovském výběžku, komparací těchto událostí s jinými akcemi tohoto typu v poslední době (Břeclav, Liberec, Hurbanovo a další), studiem mediálních a politických kroků v státní správě a samosprávě jsme si stanovili cíl výzkumu. Za cíl našeho výzkumu jsme si vytýčili poznání možností, které učitel jako osobnost, vychovávající a vzdělávající romské žáky, má (či nemá) při ovlivňování výše jmenovaných napjatých vztahů mezi Romy a neromy.

\section{Stanovení výzkumného problému a cílů výzkumu}

Základním problémem, který v práci školy a jejího vztahu k vnějšímu společenskému životu vnímáme ve sledovaných souvislostech, je jakési odtržení školy a práce učitelů od vněǰ̌ího života. Také v událostech ve Šluknovském výběžku se ukázalo, že škola má malý vliv na řešení těchto rozporů a konfliktů. Avšak má možnost svým 
postojem k romským žákům a k jejich rodinám vyjádřit jednoznačné stanovisko. Problém je však v tom, že učitelé jsou též součástí tzv. vnější společnosti, která je již za hranicemi „skleníkového prostředí školy“. Z toho plyne i jejich ochota či neochota se vyjádřit k otázkám intolerance, rasové nenávisti, k vztahům mezi Romy a neromy. Problémem je tedy určitá dvojkolejnost učitelova jednání a vztahu k romským žákům. A také uzavřenost před snahami (které učitelé mnohdy chápou jako vnější a k nim nepřátelské) orgánů vlády (vyvolaných zase tlakem lidsko-právních snah Evropské unie), aby se zlepšil vztah $\mathrm{k}$ romským žákům, aby nebyli překládáni ve velkém množství do speciálních základních škol atd.

\section{Hlavní cíl výzkumu}

Hlavním cílem kvalitativního výzkumu bylo prozkoumání názoru romských a neromských učitelů a dalších odborníků na možnost učitele romských žáků pozitivně ovlivňovat napjaté interetnické vztahy ve společnosti.

\section{Dílčí cíle výzkumu}

1. Zjistit důležitost komunikace mezi učitelem a rodiči žáka.

2. Zjistit důležitost komunikace mezi učitelem a rodiči romského žáka.

3. Zjistit důležitost komunikace mezi učitelem a rodiči žáka jako modelu pro zlepšování interetnického napětí.

\section{Výzkumné otázky}

Základní otázka výzkumu: Je možno roli dobrého/nedobrého vztahu učitele a rodiče romského žáka považovat za jednu z pedagogických determinant, která je/není schopna se vřadit jako důležitý činitel účinně ovlivňující vědomí společnosti, směřující k zlepšení/ zhoršení vztahů mezi romskou minoritou a majoritou? 


\section{Dílčí otázky}

1. Je pro dobrou komunikaci mezi lidmi ve společnosti důležitá i dobrá komunikace učitele s rodiči jeho žáka ?

2. Myslíte si, že komunikace v zájmu žáka jako budoucího dospělého člena společnosti je mezi učitelem a rodiči romského žáka v současné době optimální a zaměření dialogu s rodiči se projevuje v zájmu zlepšování dobrých vztahů mezi majoritou a minoritou?

3. Myslíte si, že je důležité zlepšování komunikace učitelů a rodičů romského žáka jako určitého modelu dobré interetnické komunikace ve společnosti, v zájmu odstraňování interetnického napětí?

\section{Výběrový soubor}

Výběrovým souborem výzkumu se stali učitelé, odborníci v oblasti pedagogiky, sociální práce i romologie, pracovníci v oblasti státní správy a samosprávy, romští učitelé a odborníci v oblasti pedagogiky a sociální práce. Dotazovány byly jak osobnosti přímo ze Šluknovského výběžku: ze škol a samosprávy v Rumburku, Šluknově a ve Varnsdorfu, tak učitelé ze škol na Slovensku, zejména v oblasti nejsilnější koncentrace romských obyvatel, v oblasti Spiše. Byli dotazováni přední odborníci z vysokých škol a univerzit, jak z České republiky, tak ze Slovenska. Kromě toho velký vzorek dotazovaných tvořili studenti kombinovaného oboru Andragogika na Univerzitě Tomáše Bati ve Zlíně. Tito studenti již pracují v nejrůznějších sociálních, státních, samosprávných, policejních i pedagogických oborech, takže jejich dotazování přineslo řadu zkušeností z praxe.

Přehledně tedy uvedeme výběrový soubor:

1. Neromští učitelé a odborníci.

2. Neromští učitelé.

3. Romští učitelé a odborníci.

4. Romští učitelé. 


\section{Metody a techniky výzkumu}

Základním př́stupem k výzkumu, který jsme zvolili jako nejvhodnější, byla kvalitativní analýza výpovědí respondentů. Tuto analýzu jsme realizovali zejména na základě Miovského výzkumné teorie trsů. Jako základ a první část výzkumu jsme vytvořili sadu tř́ otázek Tyto otázky jsme distribuovali cíleně:

1. Určitým vybraným odborníkům, u nichž výzkumník předpokládal vysokou erudici, orientovanost $\mathrm{v}$ otázkách výzku$\mathrm{mu}$, pedagogickou, andragogikou, sociální odbornost, ochotu a vnitřní potřebu nepostavit se k otázkám neutrálněči lhostejně. Tento př́istup měl charakter tzv. delfské metody, v rámci níž odpovídají výzkumníkovi vybraní specialisté na položené otázky a na jejich základě výzkumník může vytvořit formou komparace a zobecnění dílčí vymezení či teorii problému.

2. Určitým vybraným školám ve Šluknovském výběžku, se kterými jsme v rámci setkávání učitelů romských žáků měli dlouholeté zkušenosti a školám v oblasti východoslovenské Spiše, s nimiž jsme již dřive komunikovali v rámci dlouhodobých, longitudinálních výzkumů v romských osadách. Důvodem bylo, že zde je největší koncentrace Romů v Evropě.

3. Určitým vybraným romským učitelům a odborníkům. Tento výběr respondentů byl také cílený a vyplýval z informovanosti výzkumníka o romských učitelích v různých školách ČR a SR.

4. Studentům andragogiky kombinovaného studia na Ústavu pedagogických věd Fakulty humanitních studií Univerzity Tomáše Bati ve Zlíně. Zde je výzkumník jejich učitelem, ale otázky jim zadal nikoliv jako úkol, ale prosbu, o níž se mohli studenti rozhodnout naprosto dobrovolně. Otázky nebyly podmíněny žádnou zkouškou, což vyvolalo u studentů možnost se svobodně vyjádřit, zamyslet se opravdu nad podstatou zkoumaného problému. Návratnost odpovědí byla vysoká a studenti se k otázkám vyjadřovali velmi kompetentně a s vysokou mírou citlivosti k vymezenému problému. 


\section{Metody a techniky výzkumu}

Pro výzkumnou analýzu jsme zvolili kvalitativní metodu zkoumání. Východiskem byl pilotní výzkum.

\section{Interpretace výsledků}

Pro interpretaci odpovědí respondentů a získání obecných závěrů jsme použili kvalitativní metodu. Z publikací, které popisují, jak získat kvalitativní analýzou obecné závěry (např. Šed'ová, 2007, s. 207, nebo Strauss, Corbinová, 1999), jsme vybrali metodu vytváření trsů od psychologa Miovského:

Metoda vytváření trsů slouží obvykle k tomu, abychom seskupili a konceptualizovali určité výroky do skupin, např. dle rozlišení určitých jevů, místa, př́padů atd. Tyto skupiny (trsy) by měly vznikat na základě vzájemného překryvu (podobnosti) mezi identifikovanými jednotkami. Tímto procesem vznikají obecnější, induktivně zformované kategorie, jejichž zařazení do dané skupiny (trsu) je asociováno s určitými opakujícími se znaky, určitým charakteristickým uspořádáním atd. (Miovský, 2006, s. 221).

\section{Analýza dílčích cílů výzkumu}

Nejprve jsme v odpovědích hledali jednotky informací:

\section{A. Důležitost komunikace mezi učitelem a rodiči žáka}

Toto zjištování bylo realizováno pomocí otázky číslo jedna:

1. Je pro dobrou komunikaci mezi lidmi ve společnosti důležitá i dobrá a vstřícná komunikace učitele s rodiči jeho žáka - a když ano, tak proč?

Neromští odborníci:

1. odbornice: učitelka (anonymně) 
Samožrejmě ano.

Komunikace s rodiči vede ke zlepšení komunikace se žákem.

Uvědomění si spolupráce učitele s rodiči vede ke zlepšení chování žáka.

\section{2. odborník: Doc. PhDr. Boris Titzl, PhD.}

Jednoznačně ano.

Komunikace je spís vzájemné dorozumívání.

Smyslem komunikace je nalézání společného dorozumění.

\section{3. odbornice: Prof. PhDr. Alena Vališová, CSc.}

Samožrejmě.

Forma komunikace znamená nejen rodičovské schůzky, ale i individuální konzultace učitele s rodiči.

Škola a učitel může mnoho pozitivního, ale nemůže suplovat rodinu a společnost. Je více determinant a ty v současnosti negativně ovlivňují rodinu (uspěchaná doba).

\section{Neromští učitelé:}

\section{1. učitelka Emília Procházková}

Vlídná komunikace-základ rovnocenné spolupráce.

Učiteli i rodiči by mělo jít o stejnou věc - výchovu a vzdělávání dítěte.

\section{2. učitelka Mgr. Jana Vomelová}

Ano.

Komunikace je jedna z důležitých situací, při kterých se ukazuje vychovanost společnosti.

Komunikační dovednosti a zoládání sociálních situací učitelem je potřebné.

\section{Romští učitelé a odborníci:}

\section{1. učitelka ZŠ: Mgr. Júlia Kitanovská}

Vzděláváni dětí je založeno na vzájemné komunikaci. Bez té nelze vzdělávat.

Každý vstř́cný krok učiněný vzájemnou komunikací dvou stran, müže přinést změnu k lepšimu.

Pokud je komunikace prererušena, anebo knínedochází vůbec, tak oběma stranám chybi informace $k$ tomu, aby pochopily jeden druhého.

A z toho vznikají často nedorozumění a negativní postoje. 


\section{2. učitel (univerzitní): Mgr. Ivan Rác, PhD.}

Komunikácia skvalitňuje spoluprácu trojuholnika učitel' - žiak - rodič.

$V$ prípade, že by k efektíonej, produktíonej, dobrej komunikácii nedochádzalo, je tu vysoký predpoklad vzniku komunikačnej bariéry,

$V$ mnohých smeroch to vedie $k$ problémom nielen vo vyučovacom procese, ale aj v samotných medziludských vztahoch.

\section{Studenti andragogiky Hana Filípková}

Je nutné podporovat vytvoření a udržení vstřícné komunikace mezi pedagogy a rodiči romských žáků.

Potřebujeme, aby učitelé dětí z romských rodin nebyli jenom pedagogové, ale také andragogové.

Základním předpokladem je, aby si pedagog získal dưvěru romské menšiny.

Pokud se podaři pedagogüm získat si vstřínost rodičů romských dětí, logicky se zvýší vzdělanost romských žáků. Pak nastane situace, kdy Romové budou zastávat v zaměstnání čím dále více postů středoškolské či dokonce vysokoškolské úrovně. Díky takové změně pak budou většinovou společností zcela přijati.

\section{Tereza Semelová}

Ano, komunikace je důležitá.

Rodiče mají na ditě mnohem větší vliv než učitel, komunikací mohou ovlivnit nežádoucí chování.

\section{Jana Smílková}

Komunikace učitele s rodiči žáků je nutná, jelikož základni výchova a celkové pưsobení na děti se odehrává $v$ interakcích mezi rodiči a dětmi v rodině.

Zde je třeba hledat základni zdroje a možnosti koordinace a navázání učitele na výchovné působení na děti pro jejich v̌sestranný rozvoj.

\section{Andrea Šilhárová}

Ano, protože rodiče mají na děti velký vliv.

Rodiče by měli s učiteli spolupracovat. 


\section{Interpretace a shrnutí prvního cíle, otázky}

$\mathrm{V}$ této části analýzy a interpretace výzkumného tématu jsme sledovali, zdali je důležitá komunikace učitele s rodiči jeho žáka. U všech respondentů znělo jednohlasně s některými obměnami: Ano, samozřejmě, jednoznačně ano, komunikace je nutná, je důležitá, zkvalitňuje práci trojúhelníka učitel-rodič-žák, má pozitivní vliv na vzdělávání žáka. Jedna z respondentek vztáhla tuto odpověd' již na důležitost komunikace učitele ve vztahu k romskému žáku a jeho rodičům a akcentovala andragogikou roli učitele:

Vzhledem k tomu, že komunikace je základním rysem společnosti, je důležité, aby se ubirala pozitioním směrem. Je nutné podporovat vytooření a udržení vstříné komunikace mezi pedagogy a rodiči romských žákư. Pokud se podaři pedagogům ziskat si vstřícnost rodičů romských dětí, logicky se zoýší vzdělanost romských žáku․ Pak nastane situace, kdy Romové budou zastávat v zaměstnání čím dále více postů středoškolské či dokonce vysokoškolské úrovně. Díky takové změně pak budou většinovou společností zcela príjati (Filípková, studentka andragogiky).

\section{B. Důležitost komunikace mezi učitelem a rodiči romského žáka}

Úroveň důležitosti komunikace s rodiči romských žáků ve vztahu k výchově a vzdělávání romských žáků ve škole jsme sledovali položením otázky číslo dvě:

2. Myslíte si, že tato komunikace v zájmu žáka jako budoucího dospělého člena společnosti je mezi učitelem a rodiči romského žáka v současné době optimální a zdali se učitelovo zaměření dialogu s rodiči projevuje v zájmu zlepšování dobrých vztahů mezi majoritou a minoritou? $\mathrm{V}$ převaze kladného či záporného posouzení uved'te prosím důvody, které to podle Vašeho soudu způsobují.

Znovu jsme převedli odpovědi jednotlivých respondentů do jednotek informací, které byli v následném postupu dále zobecňovány do kategorií a poté do skupin kategorií (trsů).

Neromští odborníci:

1. odbornice: učitelka (anonymně)

Žiak si postupne vypestuje pozitívny vztah $k$ sebahodnoteniu.

Snaži sa o korekciu svojho správania aj bez zásahov zo strany učitel’a a rodiča. 


\section{2. odborník: Doc. PhDr. Boris Titzl, PhD.}

Přiliš obecně a hlavně široce postavená otázka.

Učitel může i chtít a $k$ rodičưm romského žáka se bliž nedostane.

Nebo rodiče by rádi (jsou takoví), kdyby jim někdo poradil a u učitele mohou zaregistrovat skrytou predpojatost.

Bylo by zajímavé zjištovat, kolik je skrytého rasismu mezi učitelstvem, a také-kolik je zklamání nad snahou, která vyšuměla do prázdna.

\section{3. odbornice: Prof. PhDr. Alena Vališová, CSc.}

Nechci zobecňovat, ale myslím si, že komunikace romských rodičů se školou není dostatečná.

Z obou stran převládá nezájem, učitelé považují kontakty s rodiči romských dětí za zbytečně, neefektioní, a rodiče zase nemají chut' školu navštívit, většinou se kontaktují, jen když jsou s jejich dětmi problémy, neřku li, že mají pocit diskriminace jejich dětí.

Na navštěvování rodin romských žáků kantoři nemaji čas, a opět to často považuji za zbytečné. Abych pravdu řekla, nevím, jak z toho ven. Je to léta "začarovaný kruh".

\section{Neromští učitelé}

\section{1. učitelka Emília Procházková}

Optimální neni, mnozí romští rodiče nemají zájem o vzdělávání soých potomků nebo zájem předstírají.

Když má romský rodič pocit, že je ve škole dobře přijat a vyslechnut, řekne víc, než chtěl, prislibí větši pomoc při vzděláváni potomka, ale sliby maji krátkodobý charakter.

\section{2. učitelka Mgr. Jana Vomelová}

Ano je optimální.

Komunikace mezi učitelem a rodičem romského žáka je vedena jako rovnocenný dia$\log$.

U nás na škole rozhovor směřuje vždy jen pro dobro žáka.

\section{Romští učitelé a odborníci}

\section{1. učitelka ZŠ: Mgr. Júlia Kitanovská}

Myslím si, že učitelé z řad majority (což, já nejsem a proto je můj názor velmi subjektioní) ještě stále neumí komunikovat s romským žákem, jsou zatíženi předsudky a hlavně velkou nechutí romské ditě posouvat vpřed...k úspěchu, k seberealizaci... 
Česká společnost již neskrývá své negativní postoje vůči Romům, jako tomu bylo dř́ve. Dnes otevřeně ukazuje na toho, koho nemá ráda. A to se děje i ve školách. Pedagogové jakoby přestávali být profesionály a v diskusích s romským dítětem sklouzávají k osobním urážkám, a narážkám na sociální statut žáka. Zde často vznikají tě̌̌ké konfliktní situace.

Pedagog s romským rodičem hovoř́ stále nadřazeně a rozhovor se nese v duchu výtek a jednostranně zaměřeného hodnocení. V mém okruhu jsou jen čtyři pedagogové $z$ dvaadvaceti, kteři jsou schopni a ochotni vnimat romského žáka, jako DÍTĚ!!!!! A podle toho s ním jednají. Jakýkoliv neúspěch ve vzdělávání romských dětí je ohodnocen slovy "no jo, Cikáni, co byste chtěli“...

\section{2. učitel (univerzitní): Mgr. Ivan Rác, PhD.}

Nemyslím si, že je komunikácia na dobrej úrooni.

Z hl'adiska formy komunikácie možno áno, jej obsah je však problematický.

A prečo? Predsudky, xenofóbia, diskriminácia, strach, neschop-nost', neinformovanost' a mnoho d'alších faktorov spôsobuje tento existujúci stav.

\section{Studenti andragogiky}

\section{Hana Filípková}

Nemyslím si, že by tento druh komunikace byl optimální.

Jedním $z$ di̊vodì je nedostatek vstřícných a empatických pedagogů, co se romské otázky týče.

Druhým důvodem, který úzce souvisí s proním, je, že Romové necítí dostatečnou důvěru $k$ učitelům svých dětí.

\section{Tereza Semelová}

$V$ tomto př́padě záleží hodně na učiteli i rodičich žáka.

Zatím vídám spíše negationí komunikaci bez snahy z obou stran.

\section{Jana Smílková}

Komunikaci učitelů s romskými rodiči je nutno zintenzívnit.

Na základě pravidelných neformálních setkání se snažit o indentifikaci problémů a následné společné řěšní pri jejich odstrañování.

\section{Andrea Šilhárová}

Myslím si, že rodič romských žáků má špatné zkušenosti se školou a nerad dochází k učiteli nebo se mu vyhýbá. 
Ale učitelé se nechovají k romským rodičům moc př́větivě. Odsuzují je, i když je neznají.

\section{Interpretace a shrnutí druhého cíle, otázky}

Po analýze výpovědí respondentů, které pocházejí z odpovědí na první otázku, zdali je důležitá pro úspěch žáka komunikace učitele s rodiči svých žáků, možná překvapí, nebo spíše ne, výsledek druhé otázky.

Téměř všichni respondenti se kromě jedné odpovědi shodli na tom, že v případě romských žáků to nefunguje. Spolupráce učitelů s romskými rodiči nejenom nefunguje ve většině případů. Ale romští učitelé psali o vyloženě negativním vztahu učitelů k žákům a jejich rodičům. Pedagožka profesorka Vališová nazvala tuto situaci začarovaným kruhem. A docent Titzl zauvažoval o možném výzkumu na téma rasismus mezi učiteli.

Romská učitelka Kitanovská z Kladna doslova píše:

Myslím si, že učitelé z r̆ad majority (což, já nejsem a proto je můj názor velmi subjektioní), ještě stále neumí komunikovat s romským žákem, jsou zatiženi predsudky a hlavně velkou nechutí romské dítě posouvat vpřed...k úspěchu, $k$ seberealizaci... Česká společnost již neskrývá své negativní postoje vůči Romům, jako tomu bylo dřive. Dnes oteořeně ukazuje na toho, koho nemá ráda. A to se děje $i$ ve školách. Pedagogové jakoby přstávali být profesionály a $v$ diskusích s romským dítětem sklouzávají k osobním urážkám, a narážkám na sociální statut žáka. Zde často vznikají těžké konfliktní situace. Romský žák si už od mala, staví obrannou zed' vưčci "bílému“, kterého odmitá respektovat, protože jím byl ponížen, a bohužel každý další komunikační neúspěch s členy majority bude tuto zed' posilovat, až přjde v sociální izolaci jedince. Ponižování se dostává romským dětem ve školách často. A to jak $z$ rady pedagogů, tak z řad ostatních žákủ. Pedagog s romským rodičem hovoři stále nadřazeně a rozhovor se nese $v$ duchu výtek a jednostranně zaměreného hodnocení. $V$ mém okruhu jsou jen čtyři pedagogové $z$ dvaadvaceti, kteři jsou schopni a ochotni vnímat romského žáka, jako DÍTĚ!!!!! A podle toho s ním jednají. Jakýkoliv neúspěch ve vzdělávání romských dětí je ohodnocen slovy "no jo, Cikáni, co byste chtěli“. Hlavni př́činu negationi komunikace ve školství spatřuji v nechuti hledat schůdná řšsení pro obě strany. Učitel se málo snaží a romský rodič není ochoten cokoli prijímat od člena majority. Situace v této zemi zrovna celé věci nepomáhá. 
Naopak odpor a netolerance obou stran se přelévá do všech sfér sociálního života, tedy $i$ do škol. Lidé se $k$ sobě prestali chovat slušně a upadla celkově i morálka. To co by se nikdy nemohlo tolerovat, se dnes bere již jako běžná norma.

\section{Důležitost komunikace mezi učitelem a rodiči žáka jako mo- delu pro zlepšování situace interetnického napětí}

Předchozí zjištění o úrovni komunikace učitele s romskými žáky a jejich rodiči spočívá $\mathrm{v}$ neochotě či nemožnosti komunikovat na obou stranách. Jak píše docent Titzl, „učitel může i chtít a k rodičům romského žáka se blíž nedostane. Nebo rodiče by rádi (jsou takoví), kdyby jim někdo poradil a u učitele mohou zaregistrovat skrytou předpojatost. Bylo by zajímavé zjištovat, kolik je skrytého rasismu mezi učitelstvem, a také - kolik je zklamání nad snahou, která vyšuměla do prázdna“. Z hlediska těchto zjištění bude nyní velmi zajímavá sonda do otázky, zdali je učitel schopný na př́kladu své komunikace s rodiči romských žáků vytvářet model vstřícné a tolerantní interetnické komunikace ve společnosti.

Neromští odborníci:

1. odbornice: učitelka (anonymně)

Áno, Lebo rómski žiaci často nemajú doma pozitívne vzory správania (napr. pre nich je krádež súčastou kultúry a nie společensky neprijatelné správanie).

2. odborník: Doc. PhDr. Boris Titzl, PhD.

Škole by velmi pomohli romští "mediátoři“.

Mohly by to být zejména matky úspěšnějšich romských žákio

3. odbornice: Prof. PhDr. Alena Vališová, CSc.

Zlepšování komunikace učitelů a rodiču romského žáka je nezbytná.

Ale nedokážu si predstavit, jak ji zlepšovat.

Neromští učitelé

1. učitelka Emília Procházková

Není co zlepšovat.

Učitel ze své podstaty „chce“, ale hlavně chtít musí i rodič. 


\section{2. učitelka Mgr. Jana Vomelová}

Ano, zlepšování komunikace je potřebné.

Bylo by dobré prijít na univerzální komunikaci, která by pomohla k lepšímu vzdělávání romských žákủ, dát rodičùm povědomost a o tom, jak je vzdělání dobré a podnětné pro lepši život jejich dětí.

Díky tomu by se odstranily bariéry, které v komunikaci jsou (správný tvar českého jazyka, pochopení nutnosti vzdělání apod.).

Dle mého názoru, napětí, která v poslední době vznikají nejen v České republice, jsou jen di̊sledky špatné politiky států. Potřebují uvolnit napětí, které je sužuje a zloba obrácená na politiky bývá podle zkušeností lidí neúčinná. Bohužel se lidé obrací se svou zlobou a nenávistí na skupinu, která je nejvíce zranitelná.

\section{Romští učitelé a odborníci}

\section{1. učitelka ZŠ: Mgr. Júlia Kitanovská}

Ano myslím si, že dobrá interetnická komunikace může v mnohém pomoci, ale nemyslím si, že by to mohla ovlionit jen sféra školstoí.

Ve škole to má začít. Tam je nutné udělat ten proní krok.

Samozřejmě, že učitel má být nositelem kladných sociálních postojů, má být empatický se schopností komunikovat a působit výchovně jak na žáka, tak i na rodiče. Ale bylo by naivní si myslet, že rasismus, extremismus a násilí dostaneme z ulic díky pozitioní komunikaci ve školství. Protože dle mého názoru sociální nepokoje, zaměřené proti Romům, jsou di̊sledkem velmi špatného vládnutí v každé zemi, kde k nim dochází. A to mohu posoudit z vlastní zkušenosti z cest po Balkáně.

\section{2. učitel (univerzitní): Mgr. Ivan Rác, PhD.}

Škola ako sekundárny výchovný činitel' určite vel'mi pozitívne pôsobí na utváranie dobrých a kvalitných medzil'udských vzt́ahov napriklad aj medzi majoritou a minoritou $v$ našej spoločnosti.

Napätie však "neodstráni" len škola, ale v tomto smere zohráva nesmierne dôležitú úlohu mediálna výchova, medializácia týchto "problémov" ako taká.

\section{Studenti andragogiky Hana Filípková}

Ano, zcela jistě (viz otázka č. 1).

\section{Tereza Semelová}

Ano. 
Jana Smílková

Myslím, že by lidé každé společnosti měli dodržovat v mezilidských vztazích základní etické zásady, toleranci a snahu o vzájemné porozumění ve vztazích vưči sobě navzájem i př́slušníkuim jiných etnických skupin a nerozlišovat dle baroy pleti či dle interkulturnich odlišností.

To je dle mého názoru jedno ze základních měřítek celkové úrovně společnosti, její integrity a kultury.

\section{Andrea Šilhárová}

Určitě je to velmi důležité pro porozumění, co po nich škola potřebuje (spolupráci).

\section{Interpretace a shrnutí třetího cíle, otázky}

$\mathrm{V}$ třetí části odpovědí je možno zaregistrovat určité rozpačité reakce respondentů. Na jedné straně považují za potřebné, že by se měla zlepšit komunikace mezi učitelem a romskými rodiči, žáky, na straně druhé jsou bezradní při navrhování metod, jak to zlepšit.

\section{Závěr}

Ve třech otázkách jsme zjistili, že učitelé a odborníci se vyjádřili $\mathrm{k}$ důležitosti vstřícné komunikace učitele $\mathrm{k}$ rodičům svých žáků velmi pozitivně.

Ve druhé otázce respondenti vyjádřili jednoznačně, že komunikace učitele s romskými rodiči a žáky neodpovídá profesionálnímu étosu učitelského povolání. Škola nevytváří důsledně model vzájemné tolerantní komunikace, která by byla použitelná pro zlepšování interetnických vztahů ve společnosti.

Následná otázka, zdali je potřebný trend zlepšování vztahů učitele a romských rodičů jeho žáků jako model pro zlepšování těchto vztahů, byla zodpovězena sice pozitivně, ale bezradně ve vztahu k metodám, které by učitel a škola měli použít. Jistě to souvisí se skepsí, zdali to je v silách a také v ochotě učitelů o to usilovat. Nejvýstižněji se vyjádřila $\mathrm{k}$ této situaci romská učitelka. Zmírňování interetnického napětí nezvládne pouze škola a učitel. Je to věcí celého společenského systému. 